Solovyanenko N.I., Shapsugova M.D.

Institute of State and Law RAS, Business and Corporate Law Department, Senior Research

Fellow, candidate of Legal Sciences

\title{
TRANSFORMATION OF LEGAL REGULATION OF RETAIL CHAINS IN THE CONTEXT OF THE CORONAVIRUS PANDEMIC
}

\begin{abstract}
Аннотация
В статье рассматриваются правовые вопросы организации и ведения бизнеса розничными торговыми сетями в условиях пандемии коронавирусной инфекции. Анализируются административные ограничения, накладываемые законом на деятельность торговых сетей. Делается вывод о том, что ликвидация избыточных административных барьеров будет способствовать реализации наиболее экономически эффективных способов взаимодействия субъектов в сфере розничной торговли. Подчеркивается необходимость частно-правовых методов регулирования, а также методов самоорганизаџии бизнеса в указанной сфере.
\end{abstract}

Summary

The article deals with the legal issues of organizing and conducting business by retail chains in the context of a coronavirus pandemic. Administrative restrictions imposed by the law on the activities of retail chains are analyzed. It is concluded that the elimination of excessive administrative barriers will contribute to the implementation of the most cost-effective ways of interaction of subjects in the field of retail trade. The need for private-law methods of regulation, as well as methods of self-organization of business in this area is emphasized.

Ключевые слова: торговая сеть, ритейл, COVID-19, предпринимательское право, пандемия коронавирусной инфекции

Keywords: retail chains, retail, COVID-19, business law, coronavirus pandemic

The Trade Act extends the prohibition of discrimination to all non-SME food retailers. In this regard, it is proposed to exclude creating an excessive administrative burden on the business n. 1-3 hours. 1 Article. 13 of the Law on Trade as duplicating the norm of Clause 8 of Article 4 of the Federal Law of July 26, 2006, № 135-Ф3 "On Protection of Competition" (hereinafter the Law on Protection of Competition). Moreover, according to paragraphs 8-10 of Art. 10 of the Law on Protection of Competition, a ban on creating discriminatory conditions, creating obstacles to access to the product market or exit from the product market to other business entities, violation of the pricing procedure established by regulatory legal acts refers to the prohibition of abuse of a dominant position by an economic entity. Thus, these standards require establishing a dominant position of an economic entity in the product market.

The Law on Trade also creates excessive administrative regulation in clause 4 of part 1 of art. 13. Since the disputability of such a transaction based on its enslavement (clause 3 of article 179 of the Civil Code of the Russian Federation) can be considered as the civil-law equivalent of an imposition, commission under the influence of an error that is significant (article 178 of the Civil Code of the Russian Federation).

It is necessary to harmonize Art. 13 of the Trade Act and Art. 39.1 of the Law on Protection of Competition, which provides for mandatory issuance of warnings on 
discrimination, creates obstacles. It is necessary to provide for the antimonopoly body to issue a mandatory warning before the antimonopoly body decides to initiate a case of violation of clauses 1, 2, 4 of part 1 of Article 13 of this Federal Law. This warning should be issued to persons specified in Part 1 of Article 39.1 of the Federal Law "On Protection of Competition", by the requirements of Article 39.1 of the Federal Law "On Protection of Competition".

Article 14 of the Law on Trade establishes a ban on the acquisition of new retail outlets for the distribution network if the latter's share in the total volume of sales exceeds twenty-five percent of the turnover of food products [1] sold within the boundaries of districts (districts) and constituent entities of the Russian Federation. Now in other antitrust laws, there are no examples of "predefined dominants" [2, p. 103-109]. As a general rule, business entities with an actual share of more than fifty percent of the market are subject to regulation only if the FAS of Russia and the court establish their dominance in each specific case of complaints about them (an analysis of the goods and market boundaries is carried out).

Besides, a general rule applies to all potential dominants - restrictions and punishment for violations are excluded for them (in most cases) if their market share does not exceed thirty-five percent (Article 5 of the Law on Protection of Competition).

The provisions of Art. 14 of the Trade Law contradict the Strategy for the Development of Trade in the Russian Federation, approved by Order of the Ministry of Industry and Trade of the Russian Federation dated December 25, 2014, № 2733, which reinforces the state's interest in increasing the number of trade facilities of various business entities, as this increases competition and creates a more comfortable environment for consumers and expanding sales channels for domestic producers.

The ban on the natural growth of the trading network reduces the investment attractiveness of the sphere of domestic trade. This creates an artificial growth limit not only for the distribution network but also for the retail market. Also, limiting the growth of networks leads to a limitation of sales by producers, i.e., ultimately, it restrains the production and growth of domestic producers and suppliers, since they have nowhere to sell additionally produced products.

This norm does not reflect the strategic interest of the state in providing the population with affordable food. The restriction on the acquisition of space is contrary to Art. 35 of the Constitution of the Russian Federation, since it limits the right of ownership and the possibility of its acquisition.

When establishing a ban on the organic growth of the distribution network, the specifics of trade in remote and inaccessible areas were not considered. Also, the indirect restriction imposed on the growth of trade in non-food products and the sale of suppliers of non-food products was not taken into account.

In the 2016 Report on the State of Competition in the Russian Federation [3], the FAS Russia notes that the various formats of trading at home, supermarket, and hypermarket) do not compete with each other due to differences in assortment and placement features.

Each trading format is unique for the consumer, as it provides different services for the selection and quality (including a variety of assortment, price level, and related services), and for the manufacturer (manufacturers of different volumes and types of goods require different trade formats as distribution channels) (Strategy for the development of trade in the Russian Federation). Limiting the share means restricting the organic growth of the distribution network and restricting the consumer from receiving services of the distribution network. The ban on the organic growth of the distribution network leads to a decrease in the construction of new retail 
facilities and a warehouse network. Such a ban directly affects the limitation of the growth of the commercial real estate market, and the lease of commercial real estate, tax losses due to the limitation of the growth of retail chains. The place of the distribution network in the structure of the food market is determined by multi-commodity, and it is this feature that gives the network a significant market advantage [ 4, p. 7-9].

In this context, the establishment of restrictions on the organic growth of the distribution network seems redundant. In this regard, we consider it possible to increase the threshold value of a market share, limiting the further growth of the trading network within the administrative region, from twenty-five to thirty-five percent.

The results of the analysis of the regulatory impact of Articles 9 and 13, 14 of the Law on the formation of commercial conditions for trading networks and suppliers allow us to conclude that they need to be adjusted (amendments).

The current version of part 2 of article 14 of the Law on Trade stipulates that a transaction concluded in violation of the requirements of paragraph 1 of Article 14 of the Law on Trade shall be void. These requirements include a ban on the purchase/rental of additional retail space, provided that the share of the business entity exceeds the statutory limit for all sold food products in monetary terms for the previous financial year within the boundaries of the constituent entity of the Russian Federation, including within the city of federal the meanings of Moscow or St. Petersburg, within the boundaries of a municipal district, urban district.

In practice, to resolve the issue of compliance / non-compliance when the trade network agrees on the acquisition/lease of an additional area of retail facilities of the prohibitions provided for in Part 1 of Art. 14 of the Law on Trade only based on the norm of the Law is not always possible.

Following the methodology approved by Decree of the Government of the Russian Federation dated 04.05.2010 № 305, information on the total volume of all food products sold in the reporting year within the boundaries of the constituent entity of the Russian Federation, including cities of federal significance Moscow and St. Petersburg, and within the boundaries of the municipal the district, urban district, in monetary terms, is posted by Rosstat on its official website on the Internet annually, until May 1 of the year following the reporting year. According to the methodology prohibition provided for by Part 1 of Art. 14 of the Law on Trade, it applies from the moment of the official publication of Rosstat the specified information. This prohibition does not apply to transactions in the trading network, the share of which, according to the latest data from Rosstat, did not exceed the maximum volume of all food products sold in the current year if these transactions were completed before the date of the official publication of Rosstat information on the total volume of all food products sold in the previous (reporting) year and does not entail the recognition of such transactions invalid.

Thus, in a number of cases, it is impossible to unequivocally establish whether an explicit prohibition established by Law has been violated. The satisfaction of the requirement to apply the consequences of the invalidity of a void transaction arises from the court declaring the contract invalid, but such recognition by the court may be refused, which is confirmed by judicial practice. In this regard, it is advisable at the level of federal Law to recognize such transactions as disputable. Under the general rule enshrined in part 1 of article 168 of the Civil Code of the Russian Federation, a transaction violates the requirements of Law, or another legal act is disputable.

As a possible change in part 2 of article 14 of the Law on Trade, it may be suggested that transactions made in violation of the requirements provided for in paragraph 1 of this article are 
considered disputable, provided that the requirement to invalidate the disputed transaction and to apply the consequences of the invalidity of such a transaction may be brought to court by any interested person, including the federal executive body, carrying out the functions of adopting regulatory legal acts and monitoring compliance with antitrust laws, if such a transaction infringes on public interests or the rights and legally protected interests of third parties.

Public interests are in free use according to part 1 of article 34 of the Constitution of the Russian Federation by any person of their abilities and property for entrepreneurial and other economic activity, including trade, not prohibited by Law. The protection of public interests by the antimonopoly body is based on the provisions of Part 2 of Art. 34 of the Russian Federation's Constitution does not allow economic activity aimed at monopolization and unfair competition. The public interest is to observe fair competition - to prevent and suppress any actions of business entities (groups of persons) that are aimed at obtaining advantages in carrying out an entrepreneurial activity, which contradict the laws of the Russian Federation, business customs, the requirements of integrity, reasonableness, and fairness and caused or may cause losses other business entities.

The expected effect of the proposed changes will be the removal of restrictions on the trading activities of large retail chains and suppliers in their relationships with each other, which will lead to the creation of equal opportunities for the unhindered opening, expansion, and conduct of business by business entities of any size (small, medium, large), regardless the trading format is chosen by the business entity under stable business conditions, a comprehensive guarantee of rights and minimizing administrative impact.

By the Strategy for the Development of Trade in the Russian Federation, all formats of trade, regardless of size, will receive the right to unhindered and natural development without government interference due to increased entrepreneurial activity, changes in consumer preferences, and citizens' desire for a comfortable living environment.

The ability to freely determine the conditions for the delivery of goods will restore the competitive market environment, which will ultimately lead to increased consumer welfare and the creation of equal non-discriminatory conditions for the interaction of suppliers and distribution networks. Reducing the regulatory burden will contribute to the development of selfregulation in relations between large suppliers and large retail chains.

The development of retail chains and their high competition with each other will expand the capabilities of large producers of goods for marketing their products, as large retail chains are as important a distribution channel for large producers as small trading formats are for small and medium producers. Small and medium-sized trading entities should become a specific sales channel, primarily for small and medium-sized suppliers. At the same time, the development of large retail chains will positively affect the development of small retail formats, the advantages of which are an individual approach to customers, the ability to work in a narrow product specialization, and also be a sales channel for small and medium-sized domestic producers, including agricultural producers, producers of unique goods.

The formation of a comfortable consumer environment and an increase in the efficiency of the trade infrastructure, the investment attractiveness of the retail sector and the trading industry as a whole, as well as the level of entrepreneurial activity, are in line with the target indicators of the Trade Development Strategy in the Russian Federation (the number of business entities operating in the retail sector, the number of stationary retail facilities all formats, the provision of the population with the area of retail facilities, differentiated by various formats, the share of Internet commerce, the dynamics of fixed capital investments in retail at the end of the year). 
This will also give impetus to the growth of related industries: commercial leasing and construction, due to the opening of new retail space.

The development of a multi-format, highly competitive retail infrastructure will make it possible to achieve the objectives of ensuring food security regardless of changes in external and internal conditions (paragraph 17 "c", "and", "l" of Presidential Decree № 20 of January 21, 2020 "On Approving the Doctrine" food security of the Russian Federation") and will lead to the improvement of legislation on trade activities, will remove excessive administrative barriers to the implementation of trade activities, which will become an incentive for the development of entrepreneurial activity in the Russian Federation [5] .

\section{References}

1. Maslova V.A. The concept of "food product" and its legal meaning for contracts between retail chains and suppliers // Material prepared for the PCA "Consultant plus. [Electronic resource] ATP "Consultant Plus" (accessed date 04.25.2020)

2. Spiridonova A.V. Antitrust restrictions on the share of retail chains in the food market // Actual problems of Russian Law. 2018. №. 11.

3. FAS report on the state of competition for 2016 [Electronic resource] https://fas.gov.ru/documents/596439 (accessed 04/22/2020)

4. Likhushina E.A. Evaluation of the "market power" of the distribution network from the point of view of monopsony - the dominant position of the buyer // Competition law. 2016. № 3.

5. Development problems and prospects of business law in modern economic conditions / Budnikova Yu.E., Bulgakova L.I., Gabov A.V., Zankovsky S.S., Kleandrov M.I., Laletina A.S., Laptev V. A., Lizikova M.S., Moturenko S.M., Netesova M.S., Sazonova E.S., Nikitin V.V., Ovchinnikova Yu.S., Pushkarev M.S., Smolina O.S. , Solovyanenko N.I., Shapsugova M.D. M.: IGP RAS , 2019. [Electronic resource] https://www.elibrary.ru/item.asp?id=41556856 (accessed 04/20/2020) 